\title{
Vocational Campus Readiness In The Disruption Era: A Case Study In Aviation Polytechnic of Surabaya
}

\author{
Linda Winiasri1,2,a*, Luthfiyah Nurlaela1,b, and Meini Sondang Sumbawati1,c \\ ${ }_{1}^{1}$ Postgraduate Vocational Education, Universitas Negeri Surabaya, Surabaya, Indonesia \\ 2 Politeknik Penerbangan Surabaya, Surabaya, Indonesia \\ a winiasri@gmail.com; b luthfiyahnurlaela@unesa.ac.id; c meinisondang@unesa.ac.id \\ ${ }^{*}$ Corresponding Author \\ Whatsapp Number [085729330525]
}

How to Cite : Winiasri, L., Nurlaela, L., Sumbawati, M., S. (2020). Vocational Campus Readiness In The Disruption Era: A Case Study In Aviation Polytechnic of Surabaya. International Journal for Educational and Vocational Studies, 2 (6), 407-411. DOl: https://doi.org/10.29103/ijevs.v2i6.2570

\section{ARTICLE HISTORY}

Received: 13 March 2020

Revised: 22 April 2020

Accepted: 15 May 2020

\section{KEYWORDS}

Disruption;

Campus readiness;

Competence;

Education implementation;

Vocation;

\begin{abstract}
The era of disruption requires change and adaptation in all fields. The education sector is also expected to be able to adapt, especially for vocational education. How graduates from vocational education should be, and how the readiness of vocational campus in dealing with it. This research is a preliminary study using a literature review and observation approach on the Surabaya Aviation Polytechnic as one of the vocational colleges of the Ministry of Transportation. Campus readiness is measured by the competence and skills of cadets, as well as the education carried out there. Competence and preparedness of cadets are measured from critical thinking and problem solving skills, collaboration and leadership, dexterity and adaptability, initiative and entrepreneurial spirit, able to communicate effectively both orally and in writing, able to access and analyze information, and have curiosity and imagination. The next discussion is about learning, how education is carried out. Education is carried out based on four pillars of education, namely learning to know, lerning to do, learning to be and learning to live together. College readiness is also measurable and achievable, which is overseen by the Quality Assurance Unit and the Internal Inspection Unit who continue to work to ensure that the Quality Standards continue to run in accordance with established regulations. Suggestions offered for the Surabaya Aviation Polytechnic are to keep on updating the development of the aviation industry, continue to improve cooperation with stake holders, and continue to improve the quality of human resources educators and management.
\end{abstract}

This is an open access article under the CC-BY-SA license.

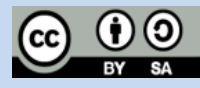

\section{INTRODUCTION}

Lately, we often hear the words disruption, disruptive innovation, disruptive technology, disruptive mindset, disruptive leaders, and so on becoming increasingly popular in higher education circles and the wider community (Ohoitimur, 2018). As widely described by Kasali (2017) the term "disruption" first emerged in the context of business, investment and finance. But later it expanded its influence in many areas of life: politics, the world of entertainment, government, social, leadership, and education. What is disruption? What is the impact on the development of science? Is it true that the era of disruption has fundamentally threatened higher education institutions? This last question surfaced among others through Sudaryono's article (2017) entitled "Mass Suicide in Higher Education Towards Assembling Education", which in essence is how the campus is ready in the era of disruption?.
Prof. Sudaryono affirmed the opinion of Jim Clifton (2016) that published in one of the articles in Gallup, which stated that in broad outline questioning and worrying about the future role of higher education in supplying industrial labor in the world. Then the question arises: How to recognize future workforce needs? Do we already know the background to the 21st century's skills? Do we understand enough of the 21st century skills? Do we understand how appropriate learning is in order to prepare the generation to master 21st century skills? Do we know what to do according to our abilities and capacities as educators and prospective educators? (Zubaidah, 2016).

Studies by Trilling and Fadel (2009) show that high school graduates, diplomas and higher education are still less competent in terms of: (1) oral and written communication, (2) critical thinking and problem solving, 
(3) work ethics and professionalism, (4) work in teams and collaborate, (5) work in different groups, (6) use technology, and (7) project management and leadership.

What types of skills must graduates have in order to compete in the 21st century? Employment in the 21 st century is more international, multicultural and interconnected. In the last century there has been a significant shift from manufacturing services to services that emphasize information and knowledge (Scott, 2015a). Knowledge itself grows and expands exponentially. Information and communication technology has changed the way we learn, the nature of work that can be done, and the meaning of social relations. Joint decision making, information sharing, collaboration, innovation, and speed of work are very important aspects at this time. Cadets are expected to no longer focus on succeeding in doing manual jobs or routine work assisted by machines or work that relies on the cheap labor market. Today, indicators of success are based more on the ability to communicate, share and use information to solve complex problems, be able to adapt and innovate in responding to new demands and changing circumstances, and expanding the power of technology to create new knowledge.

New standards are needed so that students will have the competence needed in the 21 st century. The campus is challenged to find ways in order to enable students to succeed in work and life through mastering creative thinking skills, flexible problem solving, collaborating and innovating. Several sources such as Trilling \& Fadel (2009), Ledward \& Hirata (2011), Partnership for 21 Treasury Learning; Pacific Policy Research Center, and others demonstrate the importance of 21 st century skills to achieve the transformation needed.

That is a picture of the campus in general, or academic education, how the campus is engaged in the vocational field? Will the steps be different? As we know, education in Indonesia is divided into three (Harususilo, 2019), namely:

1. Academic Education. Academic Education is an education system that leads to the mastery and development of certain disciplines of science, technology, and art. The comparison between theory and practice is around 60:40.

2. Vocational Education. Vocational Education is education referring to the mastery of certain applied skills. Thus the applied education you get, you will practice more than theory. The comparison between theory and practice is around 40:60

3. Professional Education. Professional Education is a continuation of academic education, when you have obtained a Bachelor's degree (S1). Professional education is prepared for students to have jobs with special skills requirements and also get a professional degree / certain expertise.

The study was aimed to obtain information about how did Surabaya Aviation Polytechnic deal with this era of disruption ? And, is the readiness measurable and achievable?.

\section{METHODS}

This study used combination of descriptive research type to explain the phenomena that occur in the field, and literarture review to check what suppose to do. Through this research, researchers intend to describe or describe in the form of words and language naturally about the phenomenon and background of the subject. Based on the focus of his research, researchers used the research with a case study design at Surabaya Aviation Polytechnic. The research was conducted from January 2020 to May 2020. Surabaya aviation polytechnic is one of the vocational campuses that owned by the Ministry of Transportation, which has seven study programs.

This research uses techniques in the context of data collection in the field. Some data collection techniques used are:

(1) Observation technique is a direct observation of symptoms that are investigated using assistive devices that have been prepared in advance or that are held specifically for that purpose. Some information obtained from observations are space (place), actors, activities, actions, events or events, time, and feelings. Observations made by researchers by observing the activities and habits of cadets. This observation method was conducted by collecting and analyzing existing data on the Surabaya aviation polytechnic campus, as well as observing daily cadet activities.

(2) Interview technique, is a technique of data collection which is carried out through face-to-face and question and answer directly between researchers against the sources or data sources. The interview used by the researcher is a semi-structured interview, because in addition to referring to the questions that have been designed but there can be additional questions if needed. Interviews were conducted during the research time to the cadets and campus management, to find out the extent of the implementation of activities with the existing regulatory guidelines.

(3) Documentation techniques, the documentation collected in this study are documents relating to the focus of the research, namely regarding the readiness of the campus in facing the era of disruption. The results of this documentation will serve as evidence from the results of interviews and observations, so that the data obtained will be more accurate.

And not to forget, (4) Literature review is used to enrich research by analyzing existing theories to get comparisons that are in the desired direction.

Data analysis was carried out after the researcher obtained data from the research subjects, by selecting the 
data in accordance with the focus of the study. The research requires systematic data analysis which means that data analysis is carried out in a process. The process of data analysis begins with data reduction or reducing data that is not important, data presentation or drawing conclusions temporarily, and drawing conclusions from reviewing the field notes of research results so as to obtain strong conclusions.

\section{RESULTS AND DISCUSSION}

Campus readiness can be seen from how to translate the competencies and skills needed to face the 21st century. Wagner (2010) and the Change Leadership Group of Harvard University identified the competencies and survival skills needed by cadets to face life, the world of work, and citizenship in the 21st century emphasized in the following seven (7) skills:

(1) Critical thinking and problem solving skills,

(2) Collaboration and leadership,

(3) Dexterity and adaptability,

(4) Initiative and entrepreneurial spirit,

(5) Able to communicate effectively both orally and in writing,

(6) Able to access and analyze information, and

(7) Have curiosity and imagination.

The US-based Apollo Education Group identifies ten (10) skills needed by cadets to work in the 21st century, namely critical thinking skills, communication, leadership, collaboration, adaptability, productivity and accountability, innovation, global citizenship, ability and soul entrepreneurship, as well as the ability to access, analyze, and synthesize information (Barry, 2012).

Based on the results of research conducted by the OECD obtained descriptions of three (3) dimensions of learning in the 21st century, namely information, communication, and ethics and social influence (Ananiadou \& Claro, 2009). Creativity is also an important component in order to successfully face a complex world (IBM, 2010).

The US-based Partnership for 21st Century Skills (P21), identified the competencies needed in the 21st century, namely "The 4Cs" - communication, collaboration, critical thinking, and creativity. These competencies are important to be taught to cadets in the context of core subject areas and 21st century themes. Assessment and Teaching of 21st Century Skills (ATC21S) categorizes 21st Century skills into 4 categories, namely way of thinking, way of working, tools for working and skills for living in the world (Griffin, McGaw \& Care, 2012). Way of thinking includes creativity, innovation, critical thinking, problem solving, and decision making. Way of working includes the skills to communicate, collaborate and work in teams. Tools for working include awareness as global and local citizens, life and career development, and a sense of responsibility as a person and socially. Whereas skills for living in the world are skills based on information literacy, mastery of new information and communication technologies, and the ability to learn and work through digital social networks.

Delors Report (1996) of the International Commission on Education for the Twenty-first Century, proposes four learning visions namely knowledge, understanding, competence for life, and competence for action. In addition to this vision, four principles are known as the four pillars of education, namely learning to know, lerning to do, learning to be and learning to live together. This framework of thought is still relevant to current educational interests and can be developed according to the needs of the 21st century (Scott, 2015b).

The development of this mindset is broadly included in the four pillars of education, namely learning to know, lerning to do, learning to be and learning to live together, which have been seen to be applied at Surabaya Polytechnic (Poltekbang). The description is as follows:

Learning to Know. Learning to know is an activity to acquire, deepen and utilize knowledge material. Material mastery is one of the important things for cadets in the 21st century. Youth must also have the will to learn throughout their lives. This means cadets must continuously assess their abilities about what is already known and continue to feel the need to strengthen understanding for the success of their lives later. Cadets must be prepared to always learn when facing new situations that require new skills. Learning in the 21 st century should place more emphasis on the theme of interdisciplinary learning. Four specific themes that are relevant to modern life are: 1) global awareness; 2) financial, economic, business and entrepreneurial literacy; 3) citizenship literacy; and 4) health literacy. Although the four specific themes are not carried out globally by the Surabaya Poltekbang campus in detail, they are introduced to the competition.

Learning to Do. In order to be able to adapt and adapt in a rapidly developing society, individuals need to learn to work. Cadets and adults alike need academic and applied knowledge, can link knowledge and skills, are creative and adaptive, and are able to transform all of these aspects into valuable skills. All of these things have been implemented by the Surabaya Poltekbang Campus.

Learning to Be. Academic and cognitive skills are indeed important skills for a cadet, but are not the only skills needed for cadets to be successful. Cadets who have fundamental cognitive competence are qualified individuals and identities. Cadets like this are able to respond to failure and conflict and crisis, and are ready to face and overcome difficult problems in the 21st century. In particular, young people must be able to work and study together with various groups in various types of work and social environments, and be able to adapt to changing times. 
Learning to Live Together. Various evidence shows that cadets who work cooperatively can reach a higher level of ability if viewed from the results of thought and the ability to store information in a long period of time than cadets who work individually. Studying together will provide an opportunity for cadets to be actively involved in discussions, constantly monitoring their learning strategies and achievements and becoming critical thinkers.

Answering the second question in the formulation of the problem above, namely: Is the readiness sufficiently measurable and achievable? The answer is yes. Surabaya Poltekbang has a Quality Assurance Unit and an Internal Inspection Unit that continues to work to ensure that the Quality Standards continue to run in accordance with established regulations. Although not all of them are perfect, they continue to process and are not resistant to change. Must be willing to change and accept input from other parties. This condition has been discussed in an article from Sudaryono (2017), namely by organizing two main streams of higher education based on discovery and assembling, the concern over the possibility of bankruptcy of tertiary education is unwarranted. In addition to the existence of tertiary education can still be maintained, tertiary education will be returned to its role as a guide or guide of human civilization, not as a pembekek (imitators) what has been done by the industrial world.

\section{CONCLUSION}

The conclusions from the discussion above are:

1. This era of disruption is inevitable, as an institution with its management and teaching staff, the Poltekbang Surabaya is ready and continues to improve for the Tarunanya's readiness when graduating.

2. Surabaya Poltekbang readiness is quite measurable from the standards that have been determined and agreed upon.

\section{Suggestions offered are:}

1. Surabaya aviation Polytechnic must continue to update the situation of the aviation industry and the world.

2. Increase cooperation with stakeholders for the achievement of the quality of cadets in accordance with market demand, or even better.

3. Improving the quality of human resources educators and management for the sake of the sustainability of healthy institutions and responsive to changing times.

\section{REFERENCES}

Ahmatika, Deti. (2018). Peningkatan Kemampuan Berpikir Kritis siswa dengan Pendekatan Inquiry/Discovery. Bandung: Jurnal Euclid, ISSN 2355-1712, Vol 3 No. 1 p. 394
Ananiadou, K. and M. Claro (2009), 21st Century Skills and Competences for New Millennium Learners in OECD Countries, OECD Education Working Papers, No. 41, OECD

http://dx.doi.org/10.1787/218525261154

Clifton, J. (2016). Universities: Disruption Is Coming (19 $\mathrm{Mei}$

https://news.gallup.com/opinion/chairman/191633/un iversities-disruption-coming.aspx accessed on April 4, 2020.

Delors, J., Al Mufti, I., Amagi, I., Carneiro, R., Chiung, F., Geremek, B., Gorham, W., Kornhauser, A., Manley, M., Padrón Quero, M., Savané, M-A., Singh, K., Stavenhagen, R., Won Suhr, M. and Nanzhao, Z. (1996). Learning: The Treasure Within: Report to UNESCO of the International Commission on Education for the Twenty-First Century. Paris, UNESCO.

Griffin, P., McGaw, B., Care, E., (2012). Assessment and Teaching of 21st Century Skills, Dordrecht Heidelberg London New York : Springer, DOI 10.1007/978-94-007-2324-5

Harususilo, Y. E. (2019). Yuk Mengenal Perbedaan Pendidikan Akademik, Vokasi dan Profesi. https://edukasi.kompas.com/read/2019/12/08 /14242351/yuk-mengenal-perbedaan-pendidikan-aka demik-vokasi-dan-profesi?page $=$ all. accessed on April 4, 2020.

IBM, (2010). Global CEO Study: Creativity Selected as Most Crucial Factor for Future Success, https://www.ibm.com/news/ca/en/2010/05/20/v384864 m81427w34.html accessed on May 10, 2020

Kasali, R. (2017). Disruption: Tak ada yang tak bisa diubah sebelum dihadapi, Motivasi saja tidak cukup. Jakarta: Gramedia Pustaka Utama

Ledward, B. C., and D. Hirata. (2011). An overview of 21st century skills. Summary of 21st Century Skills for Students and Teachers, by Pacific Policy Research Center. Honolulu: Kamehameha Schools-Research \& Evaluation.

Ohoitimur, J. (2018). Disrupsi:Tantangan bagi Perkembangan Ilmu Pengetahuan dan Peluang bagi Lembaga Pendidikan Tinggi. RESPONS volume 23 no. 02 (2018): 143-166.

P21. (2007a). The Intellectual and Policy Foundations of the 21st Century Skills Framework. Washington DC, Partnership for 21st Century Skills.

P21. (2007b). 21st Century Curriculum and Instruction. Washington DC, Partnership for 21st Century Skills.

P21. (2008). 21st Century Skills, Education \& Competitiveness. Washington DC, Partnership for 21st Century Skills.

P21. (2011). Framework for 21st Century Learning. Washington DC, Partnership for 21st Century Skills. 
A Call to Action for Policymakers and Educators. Washington DC, Partnership for 21st Century Skills.

Pacific Policy Research Center. (2010). 21st Century Skills for Students and Teachers. Honolulu: Kamehameha Schools, Research \& Evaluation Division.

Scott, C.L. (2015a). The Futures of Learning 1: Why must learning content and methods change in the 21st century? UNESCO Education Research and Foresight, Paris. [ERF Working Papers Series, No. 13].

Scott, C.L. (2015b). The Futures of Learning 2: What kind of learning for the 21st century? UNESCO Education Research and Foresight, Paris. [ERF Working Papers Series, No. 14].

Sudaryono. (2017). "Bunuh Diri Masal Perguruan Tinggi Menuju Pendidikan Asembling," Kompas (29 Agustus 2017).

https://kompas.id/baca/opini/2017/08/29/menuju-pendi dikan-asembling/ accessed on April 4, 2020

Trilling, B. and Fadel, C. (2009). 21st Century Skills: Learning for Life in Our Times. San Francisco, California., Jossey-Bass/John Wiley \& Sons, Inc.

Wagner, T. (2010). Overcoming The Global Achievement Gap (online). Cambridge,

Zubaidah, S. (2016). Keterampilan Abad Ke-21: Keterampilan Yang Diajarkan Melalui Pembelajaran. Seminar Nasional Pendidikan . 10 Desember 2016. 